\title{
God, Free Will, and Time: the Free Will Offense Part II
}

\section{J. L. Schellenberg}

In other work I have argued that libertarian free will, assuming we possess it, provides no solution for the problem of evil but rather presents theism with an added problem. Instead of putting its best foot forward by emphasizing such free will, so I said, theism is exposing its Achilles' heel. In this paper I want to develop the Free Will Offense in another direction by bringing into our thinking about free will a fuller awareness of evolutionary time. Doing so, as I will show, complicates things nicely, enabling fresh insights on God and free will. Specifically, our present existence at a very early stage in the time available for the development of intelligent and spiritually sensitive forms of life on our planet, together with the fact of our evident psychological and moral immaturity and certain recent developments in compatibilist thought, points to an entirely new way of reasoning from our actual possession of libertarian free will to atheism. I shall once again assume with theists that we do indeed possess such free will: an ability to exercise control over one's choices that is incompatible with determinism. I shall also assume, for the sake of argument, that a God would wish to give such free will to some creatures on a planet like ours, a planet featuring processes of evolutionary development. (That life is deeply bound up with evolution is of course a view that no rational theist today will reject.)

The key idea is that, in response to those who in a philosophical context confidently state that a God would give creatures libertarian free will, we can raise not only the question whether a God would do so but also this question: for whom? In an evolutionary world, processes yielding and modifying life unfold incredibly slowly with species following one another over unthinkably long periods of time. So which creatures in the evolutionary process should we expect to have libertarian free will, supposing a God is behind it all? Would such free will be given to creatures 
at a stage of development like ours? (And let us generously take 'our' stage to include the entire period in which there have been members of Homo sapiens both anatomically and behaviourally like humans today - which, though hard to pin down exactly, has in science been estimated to be the period of about the past 50,000 years. $)^{1}$ My aim is to show that the affirmative answer to this question, which the theist needs, is one there is good reason to deny.

My case for this conclusion is divided into two parts. In the first, I argue that there is no good, non-question-begging reason to think that the answer the theist needs is true. In the second, I argue that there is, moreover, sufficient support for the view that it is false.

Theists in philosophy haven't spent any time worrying about whether, instead of beings like ourselves, creatures at another stage of evolution would possess libertarian free will, if there were a God. Rather, we find it uncritically assumed that if the answer to the question whether a God would give creatures libertarian free will is affirmative, then we should expect, on the assumption of theism, that creatures like us would have such free will. But evolutionary sensitivity, appropriately applied, yields the insight that this doesn't follow. Many sorts of creature have come and gone prior to our evolutionary stage, and many may come and go after it. Why should creatures like us be the ones to receive the gift of libertarian free will?

Of course, for the vast majority of the history of belief in a God, theists - and also atheists! - have been quite unaware of the processes of evolution that were instrumental in

${ }^{1}$ See, for example, Klein (1999). Some scientists would say that the relevant figure is more like 100,000 years. It will not matter for my argument which way we go on this; readers may mentally adjust the figure as they deem appropriate. 
bringing us into being. (Beliefs about God and creation were forged long before Darwin.) Only for a short time have we believed that the world existed long before humans did. In the intellectual climate that so recently prevailed, the question of this paper, naturally enough, did not arise. But with the new awareness of evolution, theists have had to make some modifications to their world picture. In particular, they have had to paint in a long period of development leading up to us, with huge tracts of time in which no fully human being existed. Even this modification, however, because it is exclusively past-oriented, is not enough to raise the question of this paper. The idea that creatures like present-day humans are ones to whom libertarian free will is given, if a God with the relevant inclination exists, hasn't budged. After all, aren't we, with our intelligence and spiritual sensitivity, the pinnacle of all that has existed so far? Aren't we more impressively endowed than anything one might meet following that long winding evolutionary path back in time?

But now let's consider in a somewhat different way our place in geological time, by facing forward instead of looking back. Here we find some vital evolutionary information that theists and atheists alike have not yet factored in, which necessitates some uncomfortable new reflection about the idea that beings like us are ones to whom libertarian free will would be given by God. What is this information? Well, as already indicated, creatures both anatomically and behaviourally like humans today have been on the scene for a mere 50,000 years or so. However for all we know or justifiedly believe (and 'we' includes all those theists who take the full measure of evolution), the subsequent development of life on Earth will unfold over many more than 50,000 years, and reach heights much higher than any we have achieved. 
True, 50,000 years already seems like a lot of time to us, but that's just because of our human limitations, our shrunken imaginations. According to science - and here's an extremely important though routinely ignored piece of information - the Earth will remain habitable twenty thousand times longer, for at least another billion years. ${ }^{2}$ Thinking of the total possible lifespan of sensitive intelligence on the planet as a mile, we've travelled only about three inches!

Now, if we bring this awareness to our reflection about what a God who created an evolutionary world would or might do, it may dawn on us that there is no way of ruling out, on the assumption that such a God exists, a slow process of intelligent creaturely development over periods of time incomprehensibly large. If anything is obvious from science, it is that any creator or designer behind the things of nature is willing to take his or her time. So, coming back to us, who have only crawled those three inches, we may well be inclined to ask: Even if a God would wish to give creatures on a planet like ours libertarian free will at some time after the evolution of intelligence, why suppose it would be given to creatures as little advanced as that? There are plenty of alternative times!

Of course, we humans seem very special to ourselves. And there is also the ever-present danger, for theistic philosophers, of begging the question here: concluding that free will as we actually see it is free will as a God would want it because - however subtle or hidden to oneself the assumption may be - one is assuming that God is the author of the actual world, in which free will appears at an early stage. (If early-stage creatures in the actual world possess free will and God is our creator, then this is how God must wish things to be.) Suppose, however, that we

\footnotetext{
${ }^{2}$ This has been the standard view for some time. Recent work (though it waits to be more fully confirmed) suggests that the period of habitability may be more than twice as long perhaps as much as 2.3 billion years. See Li et al. (2009, pp. 9576-9579).
} 
avoid begging the question in this way, and also find the proper humility about our status as human beings. Why then think that the possession of libertarian free will by creatures evolutionarily like us is just what we should expect, if a God exists and gives (some) creatures such free will?

Perhaps the possession of intelligence will now be emphasized. Creatures evolutionarily like us instead of others should be expected to have libertarian free will because the meaningful and significant exercise of such free will requires the sort of intelligence only creatures like us (and perhaps some of our immediate precursors) have displayed. Suppose this to be true. Still, all we have is that humans today satisfy a necessary condition of being creatures of the sort to whom libertarian free will would be given. There may be much preventing a sufficient condition from being satisfied. (In the next section we will see that there is much.) And again we are forgetting the future. Perhaps only creatures of the future will satisfy both a necessary and sufficient condition here.

But now for another reply the theist may be tempted to try. As I have acknowledged above, even creatures like us, at our early stage of development, enjoy both intelligence and spiritual sensitivity. And a good and loving God would surely want all such creatures to be able to exercise their spiritual capacities, in particular, to be able to freely choose to love and serve God - something they could not do if they lacked libertarian free will.

This reply faces some disabling problems. First, by admitting that all intelligent and sensitive creatures would be able to exercise their spiritual capacities, if God exists, the theist only finds herself on the pathway of another atheistic argument: the argument from Divine hiddenness. But second, and more important, there is no reason to suppose, as is assumed here, 
that one exercises spiritual capacities deeply or authentically only if one's love and service of God is grounded in libertarian freedom. This assumption appears very commonly in contemporary philosophy of religion - for example, in Peter van Inwagen's recent Gifford Lectures on The Problem of Evil. ${ }^{3}$ But our familiarity with the theistic emphasis on free will so dominant in philosophy of religion today threatens to prevent the careful thought and imagination that is needed precisely here. Imagine, for example, someone caught unawares by a sense of the wonder and glory of God. Their circumstances are such that they are fully caused by factors independent of any choices of their own to have this experience, and similarly determined, through the appropriate mobilization of their various human capacities, inclinations, and reasonings, to respond to it with awe and reverence, and with the choice to seek a deeper propositional knowledge and especially knowledge by acquaintance of the Divine. Despite various obstacles represented by contrary inclinations, they are emotionally moved and rationally prompted to make a commitment to serve God wholeheartedly, and caused by the total medley of feelings and reasonings they undergo to act accordingly, finding that their emotional attachment to God and the ways of God is strengthened and enriched day by day. What is all this if not deep and authentic and spiritually sensitive love and service of God? And yet there is not a whiff of libertarian free will to be found anywhere nearby!

${ }^{3}$ See van Inwagen (2006, pp. 85, 87). In a long note on pp. 165-167 van Inwagen defends the assumption against an objection involving the unfree love for one another of members of the Trinity. His basic idea is that our love better resembles their love (and is therefore more perfect) if it comes from within; and only if we have libertarian free will is this condition satisfied. But quite apart from the fact that it is a distraction from the relevant question of what dispositions entail love to talk about where they come from, there is the problem that actions and feelings flowing from one's character or personality in a manner that is determined certainly seem to come from within! For more on related matters, see Schellenberg (2007, p. 264 and chap. 10, passim). 
If it is answered that libertarianly free choices to love and serve God are nonetheless the most intrinsically valuable, certainly more intrinsically valuable than ones that are free only in some limited compatibilist sense, we can of course point out that instrumental disvalue along with the value of compatibilist alternatives might well outweigh intrinsic value (more on this in the next section). But we can also ask whether the critic's point includes the idea that all intelligent beings made free by God are made libertarianly free. It seems that it must - otherwise, how could we infer from it, as the critic apparently wants us to do, that if creatures at a stage of evolution like ours are in any sense made free by God, they are made libertarianly free? But such a general view would seem hard to sustain given that theists have always (and appropriately) recognized that God's relationship with this set of intelligent creatures may be very different from God's relationship with that one. (Think of the unfree angels of many a theistic story.) Perhaps, so long as all sets of creatures are in one way or another granted access to the greatest good, viz., the good of relationship with God, the world might even be better for such diversity. But then so long as we assume that there may be, in actualizable evolutionary worlds, many distinguishable sets of intelligent and spiritually capable candidates for the gift of libertarian free will at various stages of development, there is no reason to suppose, given its intrinsic value, that God must give all of them libertarian free will.

Would creatures at an early stage of intelligence like ours nonetheless be deceived without libertarian free will, in a manner incompatible with a good creator's designs, given that it is part of the economy of intelligent action - of the organization and operation of such things as beliefs, desires, intentions, and choices - to believe that one does have the sort of control over how one behaves that comes only with libertarian free will? How, for example, could one think 
of oneself as deciding between two actions A and B unless one thought of oneself as able to choose either $A$ or $B$ ?

Well, then, I suppose any angels (or similar creatures) there may be are deceived too! But the more important answer here is that there is no need for deceit. Intelligent action is not as bound up with belief in libertarian free will as our critic here supposes. For the manner in which one sees oneself as deciding between two actions can vary with the nature of one's belief about whether one has libertarian free will, and a God could ensure that early intelligence was possessed of the right belief. To take an example from my previous development of the Free Will Offense: if I am informed that I lack libertarian free will but know that God has graciously determined that I shall progressively learn more of the truth and grow in understanding, forming beliefs and desires and purposes appropriate thereto, I will think of my decision between A and B in this way: I do not know which of these I will do, but whichever it is, it will be done only at the end of a process involving my thinking about the reasons for doing A and about the reasons for doing $\mathrm{B}$ and selecting the action best supported by reasons. One who goes through such a process is clearly making a decision, and this without - in the manner familar to us - thinking that she is able to do either A or B. Perhaps in going through this process it will seem as though she is able to do either A or B, but this 'seeming' is as compatible with her not being deceived as its 'seeming' to us as though the Sun goes round the Earth is compatible with our not being deceived on that matter.

I suggest, therefore, that when we factor in the information about future evolution that has to be added to scientific information about the past philosophers have already absorbed, applying it to the discussion over free will, we can see that there is no good, non-question-begging reason 
to suppose that if God exists and gives intelligent creatures libertarian free will, creatures like $u s$, at a stage of development like ours, will receive the gift. Now, of course, at this point theistic philosophers may be tempted to make a virtue of necessity (that is, to embrace what would normally be regarded as question-begging reasons) by shifting to the assumptions of their religious community as a starting point - perhaps under cover of the current 'postmodern' fad in much of academia. But that would be to exchange the pursuit of impartial understanding for a deeply and explicitly partial exposition and/or defense of views about God and the world. Which is to say, it would mean slipping from philosophy into theology.

\section{II}

Let us now consider how the other half of my case can be constructed. This, you will recall, was to be an argument for supposing not only that there is no good, non-question-begging reason for the stance the theist needs to be able to uphold on our question - that creatures in an early evolutionary stage of development like ours would be given free will, were there a God who wished to give (some) intelligent beings free will - but that there is good reason to oppose this stance as mistaken and wrong-headed.

I begin from a point already made: that we are indeed 'little advanced,' evolutionarily speaking. This term 'little advanced' was meant, in previous discussion, to be taken in a purely descriptive sense: we have traveled only 50,000 years out of what may, before intelligence on our planet is done, be a million or a billion. But now let's add to our story the fact that we - the intelligent beings who presently exist on this planet - are little advanced or immature in a normative or evaluative sense, too. We display this regularly by using our libertarian free will to 
do very self-centered and often very violent and destructive things. Our news and our novels are full of evidence that this is so. No one will deny it. And genetics is providing strong evidence that our freely chosen behaviour has always prominently manifested such tendencies. ${ }^{4}$ So when we assert that a God would give libertarian free will to creatures in a stage of development like ours, we are committed to a two-level interpretation of the notion that God would be doing so at a rather early stage - an interpretation involving both descriptive and evaluative elements: immaturity in both senses. Specifically, we are committed to saying that a God would give libertarian free will to creatures when the risk of its hurtful and destructive use was recognized as being very high. (For surely knowing other facts about the nature of creatures like us - e.g., their competitiveness and aggression - and about their evolutionary environment - e.g., adaptive pressures favouring killing - an omniscient creator would be able to recognize this risk, even if knowledge beforehand of what precisely would be done with free will is conceptually ruled out.)

Thus we can deepen and sharpen our question from before: even if a God would wish to give intelligent creatures libertarian free will, why suppose it would be given to creatures as little advanced descriptively and as likely as Early Modern Humans (aka Cro-Magnons) or even the Romans or Nazis surely were, when their evolutionary branch or leaf began to grow, to display evaluative immaturity? This is of course a rhetorical question; I am suggesting that a God would not give libertarian free will to such creatures. Some Divine input to counter evolutionary immaturity and enable growth toward greater maturity, together with a limiting of the hurtful things creatures do, seems much more appropriate to such a stage.

${ }^{4}$ See the discussion on this in Wade (2007, esp. chap. 8). 
Theists may reply that the value of the gift of free will outweighs the risk of its misuse, but the persuasiveness of such a response, though perhaps considerable when we think of ourselves and our time as representing the only possible context for such a gift, evaporates completely when, again, we bring in the neglected evolutionary insight about the future. With a billion or more years to work with, why would any intelligent creator try to cram everything good in at the beginning, especially when the chances of it leading to things bad are so high?

Thinking about intelligent life diachronically instead of synchronically (and rejecting along with the latter approach the implausible but rather common assumption that either we in our time enjoy libertarian free will or no one ever does), we therefore find ourselves with an interesting new problem. But we can make it more interesting still by considering my other main point here, which is this: the non-libertarian and compatibililist picture of free will has in recent years been rendered ever more subtly and richly and attractively. By now we have several alternative forms of free will to lay alongside the libertarian one. These include ones that might be very good for immature creatures like us to possess, whether or not libertarian free will was ever to be added but also as a kind of preparation for any eventual gift of libertarian freedom, experienced by this or future species. In particular, we have not just the traditional compatibilist's action without external constraint, which famously made Kant complain of a wretched subterfuge, but also a Frankfurtian power to constrain one's actions by higher-order desires, which has by now been (re)pictured in a variety of ways, and also Susan Wolf's free will, which involves the power to conform one's behavior to "the True and the Good."5 Thinking of

${ }^{5}$ For Harry Frankfurt's account, see Frankfurt (2003). Gary Watson produces an interesting variation on Frankfurt's theme in terms of higher order reasoning and values in Watson (2003). For Susan Wolf's view, see Wolf (1990, the quotation is from p. 79). 
what a God might do over time, instead of only about the beginning stage of an evolutionary process, we need not look upon the various forms of free will as competitors. (Thus in defending the value of what certain compatibilists have described in terms of free will, I am not committed to the view that libertarianism is false: the latter view does not have to be interpreted as including the assumption that we are free only in one significant sense - its sense - if we are free at all. $)^{6}$ Thinking in this way, we will reject the common theistic contention that God would surely give creatures who arrive at intelligence libertarian free will rather than one of its compatibilist alternatives as shortsighted and misconceived. There are more times to be considered than just one, and all these significant forms of freedom could be given, each at the appropriate time.

This point makes things even more difficult for theism because now we can say not only that libertarian free will seems inappropriate for creatures as immature as we are, but that there are significant alternative forms of freedom that appear more appropriate, and moreover may pave the way for a more intelligently timed gift of libertarian free will down the line.

Let us see how these ideas can be developed, beginning with the suggestion that giving creatures as little advanced as we are some form of compatibilist freedom instead of libertarian free will would produce significant goods for them. Here we might consider a typical example of relationship from the actual world, in which (as I am assuming) we have libertarian free will. Imagine a middle aged woman and her twenty-something daughter who has moved home to deal with an addiction problem. When not in the freedom-canceling grip of a relapse, the latter seeks to exercise her free will, in connection with such things as regularly taking her medication and

${ }^{6}$ This approach to libertarianism, it's worth noting, is taken also by prominent defenders of libertarianism. Consider, for example, Robert Kane, who in the Conclusion of his (2005, see esp. pp. 163-174) distinguishes no fewer than "five freedoms." 
attending Recovery Group, so as to help herself overcome the addiction, though progress is slow; and she also freely chooses to interact in certain ways with her mother, though often these are ways that involve disagreements and lead to blowups on her part. The former may frequently be found tearing her hair out, but exercises her free will by trying to think of something that will ameliorate the sharp disputes with her daughter and avoid what she sees as misunderstandings; working to blunt the effects of just 'not wanting to be there'; and also trying various strategies suggested by her reading and by addictions counselors, hoping in one way or another to help put her daughter on the road to recovery. After three years there are some signs of positive change, as the two of them navigate somewhat more easily through the fallout, financial and emotional, from the latest relapse. But neither is quite sure what the other is thinking by this point. The mother wonders: "Is she really looking for a job? If so, why wasn't she pounding the pavement yesterday? Maybe, after three years, it's just too easy to stay at home and let Mom take care of things? The daughter wonders: "Is she getting used to having me around, and taking advantage of my help around the house? Are we moving toward a situation of co-dependence here?" Because of the complexity and recalcitrance of the factors involved, neither can easily find a clear avenue to the sort of communication with the other that would answer her questions - or get her better questions.

This is, I would suggest, a fairly typical example of the halting manner in which solutions to problems are sought and relationships managed in the actual world - a world in which, though we have libertarian free will, our free will is hedged about by all the limitations and complexities of human life as we know it (themselves often the product of unhelpful earlier freely willed behavior), and often misdirected by a multi-faceted immaturity still all too common among us 
after 50,000 years. Evaluated within this context, the idea of our having libertarian free will may start to look somewhat less than appealing.

Now, even in the actual world, there are those rare moments when relationships seem to work much better, when reason and emotions are aligned and everything is - so we say 'flowing as it should.' (Notice the suggestion of causes for the 'flow' other than our own voluntary choices!) The next step in our little imaginary exercise is to imagine how it would be if this were the common run of things, instead of the rare exception. Suppose that, shortly after arriving at what we call human intelligence, say 50,000 years ago, God had raised us, not to a state of libertarian free will, but to a compatibilist alternative of a sort that is valorized in the Frankfurt discussions: the power, let's say, to conform our behaviour to what careful higher level reasoning and assessment of our values suggests, despite the obstacles presented, at a lower level, by contrary desires. What if, because of this power, things flowed 'as they should' among us much more often, and we were freed to explore all the higher levels of relationship instead of remaining at the surface of things or destroying each other as we so often do in the actual world? Should it really be supposed that we would be worse off, were such the case, than we are in fact?

Notice that if we had a compatibilist freedom of the sort in question, our lives would be much more similar to a God's life, in which things of necessity flow rather well. This suggests an improvement rather than deterioration. At the very least, we can say that having such freedom would be just another way of realizing the good. We would lack the privilege of libertarian free will, certainly, but at the same time we would enjoy many other privileges - as just a brief consideration of what mother-daughter relationships might be like in such a scenario should be sufficient to bring home to us! Moreover - and this is hugely important - we would avoid all the evil that has in fact come with the exercise of libertarian free will in the past 50,000 years. The 
combination of alternative good plus avoidance of moral evil appears to put such a scenario at a level, value-wise, that is well above that of the actual stage of life, on which, perforce, we play out our lives.

Now for my other suggestion from before: that creatures appearing later in the evolutionary process who received the gift of libertarian free will would be helped to use it more wisely and maturely and more fully in accord with Divine good purposes if some compatibilist scenario of the sorts I have just described were to obtain at an earlier stage, such as our own, instead of a libertarian one. Why should we suppose this to be so?

What suggests itself is that such creatures would have the benefit of a more instructive history, a clearer display, through all the ins and outs of human relationship and ambition, of how life can be made to go well. As it is, we - the libertarianly free creatures who actually exist - lack such a history. Instead, we have a record of uneasy coexistence or, much worse, rape, pillage, and war. Behaviour of these sorts, for many of us, has come to seem 'only natural.' Might we not have done better with a history different in the ways we are imagining?

Now, if in earlier stages of history people had simply been determined to do the good, doing it straightaway because they wanted to, without any thought, perhaps we would find little help in their examples. But that's only the least interesting way of picturing compatibilist freedom. We are instead imagining 50,000 years of learning to think things through and manage contrary desire, of respecting and following reason. Perhaps the next 50,000 years would be much better than they now can be were creatures with such a history to be given libertarian free will - even should the strength of contrary desire and of the propensity to reason to be on average no greater for them than they are for us in the twenty-first century. More to the point, whatever a God would in fact do, wouldn't the idea of providing creatures with the opportunity to learn from 
such an example commend itself over what has in fact been the case - viz. creatures 'starting cold' with libertarian free will in a state of great immaturity - to a good and wise God seeking to help them make the most of their free will?

Perhaps it will be said that 50,000 years of compatibilist freedom of the sort I am imagining would have turned this Earth into a paradise. That might indeed be the case, and it provides a clear indication of just how wonderfully well things could go for creatures even without libertarian free will. Moreover, there would still be this serious question for those who followed, were they to be given libertarian free will: Shall paradise be preserved or shall it be lost? (Such a scenario, come to think of it, has certain affinities with ones to be found in religious stories of the actual world!)

It seems, then, that both of my earlier suggestions are confirmed by more detailed inquiry, and thus the additional support provided by them for the claim defended in this second section of the paper - that we have good reason to deny that a God would give libertarian free will to creatures at so early a stage in the evolutionary process - is indeed available. A perfectly good and wise God creatively active in an evolutionary world like ours would ensure that the libertarian option of free will, if realized at all, came later in the day - perhaps long after the sun had set on any variety of intelligence as little prepared to handle it as we are. Which is to say that if, as I am assuming (and as theistic philosophers certainly uphold), we have libertarian free will, then we are provided with a good reason to deny that there is a God. 


\section{References}

Frankfurt, H. (2003). Freedom of the will and the concept of a person. In G. Watson (Ed.) Free will, 2d ed. New York: Oxford University Press.

Kane, R. (2005). A contemporary introduction to free will. New York: Oxford University Press.

Klein, R. (1999). The human career, 2d ed. Chicago: University of Chicago Press.

Li. K. et al. (2009). Atmospheric pressure as a natural climate regulator for a terrestrial planet with a biosphere. Proceedings of the National Academy of Sciences (USA) 24, 95769579.

Schellenberg, J. (2007). The wisdom to doubt: A justification of religious skepticism. Ithaca: Cornell University Press.

van Inwagen, P. (2006). The problem of evil. Oxford: Clarendon Press.

Wade, N. (2007). Before the dawn: Recovering the lost history of our ancestors. New York: Penguin.

Watson, G. (2003). Free agency. In In G. Watson (Ed.) Free will, 2d ed. New York: Oxford University Press.

Wolf, S. (1990). Freedom within reason. New York: Oxford University Press. 